\section{Geographic information system-based decision support for soil conservation planning in Tajikistan}

\author{
E. Bühlmann, B. Wolfgramm, D. Maselli, H. Hurni, S.R. Sanginov, and H.P. Liniger
}

\begin{abstract}
Soil erosion on sloping agricultural land poses a serious problem for the environment, as well as for production. In areas with highly erodible soils, such as those in loess zones, application of soil and water conservation measures is crucial to sustain agricultural yields and to prevent or reduce land degradation. The present study, carried out in Faizabad, Tajikistan, was designed to evaluate the potential of local conservation measures on cropland using a spatial modeling approach to provide decision-making support for the planning of spatially explicit sustainable land use. A sampling design to support comparative analysis between well-conserved units and other field units was established in order to estimate factors that determine water erosion, according to the Revised Universal Soil Loss Equation (RUSLE). Such factor-based approaches allow ready application using a geographic information system and facilitate straightforward scenario modeling in areas with limited data resources. The study showed first that assessment of erosion and conservation in an area with inhomogeneous vegetation cover requires the integration of plot-based cover. Plot-based vegetation cover can be effectively derived from high-resolution satellite imagery, providing a useful basis for plot-wise conservation planning. Furthermore, thorough field assessments showed that $25.7 \%$ of current total cropland is covered by conservation measures (terracing, agroforestry, and perennial herbaceous fodder). Assessment of the effectiveness of these local measures, combined with the RUSLE calculations, revealed that current average soil loss could be reduced through low-cost measures such as contouring (by 11\%), fodder plants (by 16\%), and drainage ditches (by 53\%). More expensive measures, such as terracing and agroforestry, can reduce erosion by as much as 63\% (for agroforestry) and 93\% (for agroforestry combined with terracing). Indeed, scenario runs for different levels of tolerable erosion rates showed that more cost-intensive and technologically advanced measures would lead to greater reduction of soil loss. However, given economic conditions in Tajikistan, it seems advisable to support the spread of low-cost and labour-extensive measures.
\end{abstract}

Key words: decision support—implementation and maintenance costs—remote sensingsoil erosion modeling-soil conservation-Tajikistan

\section{Soil erosion by water poses a major threat to long-term sustainable use of natural resources on cultivated sloping lands. Controlling erosion on such lands is crucial to sustaining agricultural yields and reduc- ing environmental damage (Pimentel et al. 1993). This is especially true for loess soils, which are known to be highly susceptible to erosion (Zhang et al. 2005). Accurate mapping, assessment, and monitoring of soil erosion on a local scale are important for conservation planning, erosion control, and management of natural resources (Lal 2001).}

Soil Loss Equation (RUSLE) for wider application by introducing improved means of computing the soil erosion factors. The RUSLE is written as

$A=L S R K C P$,

where $A$ represents average annual soil loss $\left(\mathrm{t} \mathrm{ha} \mathrm{a}^{-1} \mathrm{y}^{-1}\right), R$ is the rainfall and runoff factor (MJ mm ha ${ }^{-1} \mathrm{~h}^{-1} \mathrm{y}^{-1}$ ), and $K$ expresses soil erodibility ( $\mathrm{tha} \mathrm{h}^{-1} \mathrm{ha}^{-1} \mathrm{MJ}^{-1} \mathrm{~mm}^{-1}$ ). The quantities $L, S, C$, and $P$ are dimensionless factors representing slope length, slope angle, vegetation cover, and management practices. The main advantage of the RUSLE is that the $C$ factor can be estimated from information on vegetation form, decay, and tillage practices rather than from experimental plot data as proposed in the original USLE (Merrit et al. 2003). According to Benkobi et al. (1994), the $C$ factor, together with the LS factors (slope length and steepness), is most sensitive to soil loss. Remote sensing data have provided a useful basis for determining the $C$ factor in many erosion studies (Vrieling 2006). However, automated classification approaches that assign average $C$ factor values to each vegetation type result in smoothed estimates and the disappearance of spatial heterogeneity and variability. Such values are therefore not suitable for areas with highly inhomogeneous vegetation cover. In these areas, it is important to fill this gap by drawing a reliable map of vegetation cover as a basis for more accurate $C$ factor derivation (Wang et al. 2002). If validated with ground truth data, this can be done efficiently on the basis of high-resolution satellite imagery.

Opportunities for improved land management and conservation measures are usually integrated into erosion modeling without taking into account the present condition of

Erik Bühlmann is project leader at Grolimund \& Partner AG, Bern, Switzerland. Bettina Wolfgramm is a PostDoc Researcher, Centre of Development and Environment (CDE), University of Bern, Switzerland, based in Dushanbe, Tajikistan. Daniel Maselli is program manager for the Swiss Agency for Development and Cooperation, Berne, Switzerland. Hans Hurni is a professor and director of the CDE at the Institute of Geography, University of Bern, Bern, Switzerland. Sanginboy R. Sanginov is emergency coordinator for the Food and Agriculture Organization, Bishkek, Kyrgyzstan. Hanspeter Liniger is a senior researcher at CDE Institute of Geography, University of Bern, Bern, Switzerland. 
a field (e.g., Shiono et al. 2002). This shortcoming can be explained by the considerable investment of time and money needed to collect comprehensive datasets on current land use and conservation practices. A time-saving and easily applicable field method is thus called for to enable appropriate integration of local conservation practices with erosion modeling. Documentation of local conservation measures has been effected successfully, using the standardised tools of the World Overview of Conservation Approaches and Technologies (WOCAT 2005a, 2005b; Schwilch et al. 2009) program, which allow for comparison on a worldwide database (Liniger and Critchley 2007).

The main objective of the present paper is to show how field methods and highresolution remote sensing can be integrated with the RUSLE to model the potential of local conservation measures on cropland in marginal areas. This includes the following detailed objectives: (1) taking account of the inhomogeneous vegetation cover observed in the study area, (2) assessing and categorising fields with regard to predicted soil erosion as a basis for identifying appropriate conservation measures, and (3) evaluating the potential of local conservation measures by considering efforts and costs in relation to predicted soil loss reduction.

\section{Materials and Methods}

The study area, which measures $10 \times 6$ $\mathrm{km}(6.2 \times 3.7 \mathrm{mi})$, centered at $38.6^{\circ} \mathrm{N}$ to $69.4^{\circ} \mathrm{E}$, is located approximately $50 \mathrm{~km}$ (31 mi) east of the capital, Dushanbe (figure 1). The catchment contains three distinct landforms: the flat to gently sloping valley floor with slopes of $5 \%$ to $10 \%$; a hillslope region with moderate to steep slopes, typically $15 \%$ to $45 \%$; and a mountainous region with steep slopes of $30 \%$ to $45 \%$, with stony soils. The deep brown soils (depth $>120 \mathrm{~cm}$ [47 in]) observed on the valley floor and the hillslope region originate from loess deposition and are classified according to the Tajik soil classification system as typical brown soils and calcareous brown soils (Kuteminskij and Leonteva 1966; Ding et al. 2002). The loess deposits are highly susceptible to erosion (Jakutilov et al. 1963).

Elevation in the selected test area ranges from 1,200 to $2,500 \mathrm{~m} \mathrm{(3,940} \mathrm{to} 8,200$ $\mathrm{ft})$. Cropland is located at altitudes up to $1,900 \mathrm{~m}(6,230 \mathrm{ft})$. Farmers cultivate slopes of up to $60 \%$. The average field size is 1.3

\section{Figure 1}

Location and overview of the study area and layout of field sampling.

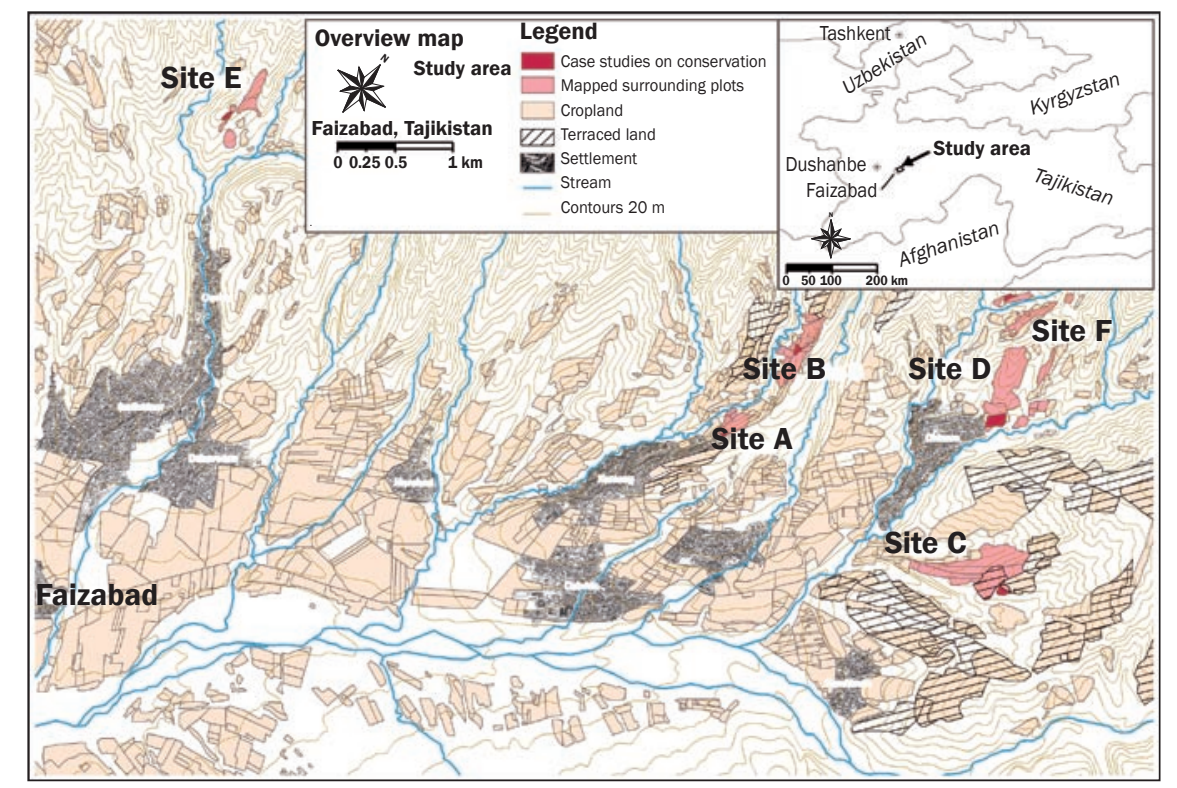

Source: Satellite image is from DigitalGlobe/Eurimage/swisstopo, NPOC.

ha $(3.2 \mathrm{ac})$, while the median is merely half this size ( 0.7 ha $[1.7 \mathrm{ac}])$, confirming the predominance of small-scale farms in the study area. The main agricultural crops are wheat, chickpeas, flax, and vegetables. Annual precipitation averages slightly below 900 $\mathrm{mm}$ (35.4 in), of which 90\% occurs from November to May, leaving the summer months nearly dry. Daily precipitation data from Faizabad weather station for the years 1988 to 2002, provided by the Tajik meteorological service, show that rainfall erosivity is greatest in the months of April and May.

Field Survey. The World Overview of Conservation Approaches and Technologies (WOCAT) field method, as well as visual land-use mapping and land-use classification, were applied to collect the most crucial information for RUSLE modeling. The field methods were applied at two different sampling levels: six case studies on conservation plots and on plots surrounding each of these conservation plots (57 in all), as well as full study area coverage (figure 1).

\section{World Overview of Conservation} Approaches and Technologies Questionnaires. Six case studies on local conservation measures were conducted using the WOCAT questionnaires on conservation technologies and approaches (WOCAT 2005a, 2005b). Information was gathered from field measurements (measuring of rill erosion features), qualitative field observations (e.g., description of soil surface conditions; area percentage covered by vegetation, crop residues, and stones), and interviews with farmers. The questionnaires addressed the specifications of the technology in question (purpose, design, and costs), as well as farmers' assessments of its advantages and disadvantages and questions regarding implementation and maintenance activities. Information on layout, effectiveness, and impact with regard to soil loss reduction and on implementation and maintenance costs served as a criterion for determining conservation scenarios. Furthermore, WOCAT interviews made it possible to elaborate highly detailed crop cycles based on field observations and on land managers' knowledge. Observations of plots surrounding the conservation plots allowed for comparative analysis of well-conserved plots and other plots.

Land-Use Mapping. A land-use map was created based on visual field observation of each plot within the study area. A multispectral QuickBird satellite image with a resolution of $2.4 \mathrm{~m}(7.9 \mathrm{ft})$ recorded on June 22, 2005, served as a basis for the field investigation. The recording date represents the stage of maximum vegetation height, just before wheat harvest. In an average year, vegetation growth declines on nonirrigated land around the end of June, due to high temperatures and lack of precipitation. During field visits conducted at the end of June 2005, all field plots within the study area were visu- 


\section{Table 1}

Overview of sources and methods used for calculation of the RUSLE (Revised Universal Soil Loss Equation) factors.

\begin{tabular}{|c|c|c|c|}
\hline RUSLE factor & Source/method & $\begin{array}{l}\text { Spatial/temporal } \\
\text { resolution }\end{array}$ & $\begin{array}{l}\text { Average annual } \\
\text { factor value }\end{array}$ \\
\hline$R$ (rainfall and runoff) & $\begin{array}{l}\text { Daily precipitation dataset from representative weather station in study area } \\
\text { Approach by Mannaerts and Gabriel }(2000) \text { to predict } I_{30} \text { based on rain }{ }_{10} \\
\text { and estimated average storm duration }\end{array}$ & $\begin{array}{l}\text { Semimonthly values } \\
\text { for the entire } \\
\text { study area }\end{array}$ & $\begin{array}{l}244.1 \\
\left(\mathrm{MJ} \mathrm{mm} \mathrm{ha-1} \mathrm{h}^{-1} \mathrm{y}^{-1}\right)\end{array}$ \\
\hline$K$ (soil erodibility) & $\begin{array}{l}\text { Soil map 1:500,000 } \\
\text { Study on texture and organic matter of soils in the test area } \\
\text { Standard RUSLE factor calculation by Renard et al. (1997) }\end{array}$ & Soil (by type) & $\begin{array}{l}0.37 \text { to } 0.42 \\
\left(\mathrm{t} \mathrm{ha} \mathrm{h} \mathrm{h}^{-1} \mathrm{ha}^{-1} \mathrm{MJ}^{-1}\right. \\
\left.\mathrm{mm}^{-1}\right)\end{array}$ \\
\hline $\begin{array}{l}\text { LS (slope length } \\
\text { and slope } \\
\text { steepness) }\end{array}$ & $\begin{array}{l}\text { Topographic map 1:50,000 with a contour interval of } 20 \mathrm{~m}(65.6 \mathrm{ft}) \text { used } \\
\text { to create a grid-based digital elevation model } \\
\text { AML Script by Van Remortel and Martin (2003) based on standard RUSLE } \\
\text { procedure but addressing overestimation }\end{array}$ & Field (by plot) & $\begin{array}{l}\text { Mean slope } \\
\text { length: } 46 \mathrm{~m} \text {, } \\
\text { Mean slope } \\
\text { steepness: } 26 \%\end{array}$ \\
\hline$P$ (support practice) & $\begin{array}{l}\text { Terraced area identified with high-resolution remote sensing } \\
\text { Standard RUSLE factor calculation by Renard et al. (1997) for terracing } \\
\text { No conservation measure applied on nonterraced fields } \\
\text { Vegetated filter strips and ditches established to account for buffer strips } \\
\text { between fields, maximum slope length limited to } 122 \mathrm{~m} \text { ( } 400 \mathrm{ft}) \\
P, C, L \text { and } S \text { factor adjustments applied for conservation scenario modeling }\end{array}$ & Field plot-wise & 0.5 to $1 *$ \\
\hline
\end{tabular}

Notes: $I_{30}=$ maximum 30-minute intensity of a rainfall event. rain ${ }_{10}=$ the amount of rainfall for days with precipitation $\geq 10.0 \mathrm{~mm}$. $\mathrm{AML}=\mathrm{Arc}$ Macro Language. WOCAT $=$ World Overview of Conservation Approaches and Technologies.

* Dimensionless factor.

ally compared, and field boundaries were sketched on a printout of the QuickBird image. The crop currently cultivated, as well as the respective land-use category, were recorded in a field protocol. In the office, field boundaries were digitised from the QuickBird image.The resulting land-use map for cropland includes 11 classes summarised as five land-use categories: annual cropland (winter wheat [Triticum aestivum], flax [Linum usitatissimum], chickpea [Cicer arietinum], vegetables, safflower [Carthamus tinctorius]); perennial cropland (Alfalfa [Medicago], esparcet [Onobrychis viciifolia]); tree/shrub cropping (orchards, vineyards, mulberry groves); mixed cropping (agroforestry); and fallow/abandoned land. The land-use map is assumed to be very sound since the classifications are based on field visits.

Fractional Vegetation Cover from HighResolution Satellite Imagery. Cropland in marginal areas often has a fractional veg- etation cover (FVC) that is inhomogeneous within a given land-use class. To represent the variability of crop density observed in Faizabad, vegetation cover information was obtained from high-resolution multispectral QuickBird satellite imagery recorded on June 22, 2005, during field work. Comparison between two vegetation indices, the Normalized Differenced Vegetation Index and the Optimised SoilAdjusted Vegetation Index (OSAVI), showed that OSAVI (Rondeaux et al. 1996) had better predictive power for FVC than the Normalized Differenced Vegetation Index. A polynomial relationship was established and validated with an independent dataset containing FVC gained from ground truthing in the study conducted by Wolfgramm (2007). The dataset was checked for landuse changes between the year when ground truth information was collected (2004) and the recording date of the satellite image
(2005). Forty-five plots where land use had remained the same were used as a validation dataset. Finally, FVC values were predicted for each pixel. The FVC pixel values derived were then averaged per field unit and served as a basis for calculation of the RUSLE $C$ factor.

RUSLE Factors. Derivation of the factors required by the RUSLE is well documented in the literature (Renard et al. 1997; Wischmeier and Smith 1978).Values assigned to the RUSLE factors are discussed below and are summarised in table 1.

Rainfall and Runoff Factor R. Detailed data on storm intensity in the region were not available for a longer time period, necessitating the use of proximate methods. A daily database from January 1988 through December 2002 was created using the rainfall parameter rain $_{10}$ (amount of rainfall for days with precipitation $\geq 10.0 \mathrm{~mm}$ ) and an estimated average storm duration (based 
on field observations and information from farmers) as a second independent predictor variable. The maximum 30-minute intensity of a rainfall event $\left(I_{30}\right)$ was calculated, adapting an approach by Mannaerts and Gabriel (2000), by dividing the amount of rainfall for days with precipitation $\geq 10.0 \mathrm{~mm}$ ( (ain $_{10}$ ) by the average monthly storm duration. Calculation of rainfall intensities was based on the assumption that two-thirds of the total precipitation of a storm event occurs within half of its duration. An average annual $R$ factor of $244.1 \mathrm{MJ} \mathrm{cm} \mathrm{ha}{ }^{-1} \mathrm{~h}^{-1}$ was derived for Faizabad. Furthermore, semimonthly erosivity values $\left(\mathrm{EI}_{30}\right)$ were calculated for inclusion in the computation of the time-varying crop and management factor $C$ (Renard et al. 1997). This average annual $R$ factor is comparable to data published by Shi et al. (2004), who reported $288 \mathrm{MJ} \mathrm{cm} \mathrm{ha}{ }^{-1} \mathrm{~h}^{-1}$ for the Three Gorge Area in China with similar monthly cumulative rainfall.

Soil Erodibility Factor K. Soil erodibility $K$ was derived on the basis of two soil types extracted from the Atlas of Natural Soil Resources at a scale of 1:500,000 (Tajikistan Academy of Science 1984). Kuteminskij and Leonteva (1966) and Jakutilov et al. (1963) analyzed the texture and organic matter content of soil types in Faizabad, taking samples from soils in different states of erosion. Based on texture and organic matter content, numeric $K$ values were assigned using a nomograph (Renard et al. 1997; Wischmeier and Smith 1978). Erodibility factors were calculated for the two prevailing soil types in the area, both formed on loess deposits. The factors amounted to $K=0.37$ for typical brown soils and $K=0.42$ for calcareous brown soils. These values are comparable to $K$ factors in other areas with similar soils on loess (e.g., Schwertmann 1987).

Topographic Factor LS. Geographic information system technology has increased estimation accuracy for slope length and steepness over large areas. This study applied an Arc Macro Language script (RUSLE Version 4) by Van Remortel and Martin (2003) to derive topographic factors from a digital elevation model. A digital elevation model with a grid cell size of $5 \mathrm{~m}(16.4 \mathrm{ft})$ was developed from a topographic map with a contour interval of $20 \mathrm{~m}(65.6 \mathrm{ft})$. Ziadat (2007) states that slope information derived from a high sampling density (using digital photogrammetry) is better than information derived from a low sampling density

\section{Table 2}

Average annual $C$ factor (crop and management) values in relation to average annual fractional vegetation cover (FVC) per land use class.

\begin{tabular}{lll}
\hline Land-use class & Average annual & Average annual \\
\hline Vegetables & $13 \%$ & 0.20 \\
Chickpea (Cicer arietinum) & $13 \%$ & 0.19 \\
Flax (Linum usitatissimum) & $27 \%$ & 0.17 \\
Winter wheat (Triticum aestivum) & $35 \%$ & 0.15 \\
Agroforestry & $36 \%$ & 0.15 \\
Safflower (Carthamus tinctorius) & $36 \%$ & 0.15 \\
Fallow & $44 \%$ & 0.12 \\
Esparcet (Onobrychis viciifolia) & $56 \%$ & 0.09 \\
Alfalfa (Medicago) & $59 \%$ & 0.08 \\
Vineyard & $60 \%$ & 0.08 \\
Mulberry (Morus) & $60 \%$ & 0.08 \\
Orchard & $66 \%$ & 0.06
\end{tabular}

(using topography maps), such as that used in the current study. Since more detailed contour layers were not available for the study area, a $5 \times 5$ smoothing filter was applied to improve the accuracy. The slope estimates were averaged for each field to smooth out errors resulting from the coarse contour data derived from the topographic map. The Arc Macro Language script is based on the RUSLE standard factor computation procedure but addresses overestimation of $L S$ factors (Van Remortel et al. 2001; Hickey 2000). A slope length of $122 \mathrm{~m}$ (400 ft) was introduced as a maximum value, since overland flow paths seldom exceed this critical distance due to interception by natural depressions, flat areas, or ditch construction (Lin et al. 2002; Renard et al. 1997).

Crop and Management Factor C. In this study, derivation of the $C$ factor focused on representing the high vegetation cover variability between different land management types on marginal cropland. Cover is highly inhomogeneous within crop classes due to land degradation, lack of inputs, and local management characteristics. The maximum fractional vegetation cover (FVC) at the time of full vegetation development was obtained from high-resolution satellite imagery for each field (see earlier section called Fractional Vegetation Cover from High-resolution Satellite Imagery) and was incorporated with crop-specific information consisting of (1) a land-use map including attributes and (2) annual vegetation cover sequences as a percentage of maximum FVC. These crop-specific sequences were based on field observations and information from farmers compiled in WOCAT questionnaires. They included timing and the nature of tillage, weeding, and harvest activities, and the effects of residue cover and mulching. For instance, maximum FVC on wheat fields was observed just before harvest at the end of June, precisely when the satellite image was recorded. After harvest, stubble and weeds were expected to provide $20 \%$ of the maximum vegetation cover, with a further decline occurring when cattle are grazed on the fields in late autumn. Winter wheat (Triticum aestivum) is sown in November (FVC $=0 \%)$. By the end of December, the cover on wheat fields was estimated to be $20 \%$ of the maximum cover; it remains at this level until the beginning of the growing season in April, when it increases further.

Twenty-four semimonthly FVC values were calculated for each field unit. These values were weighted with the rainfall erosivity value $\left(\mathrm{EI}_{30}\right)$ for the same period following the standard $C$ factor calculation procedure proposed by Renard et al. (1997). The $C$ factor values were subsequently calibrated with those obtained in semiarid and semihumid areas where land is cultivated under similar physical and agronomic conditions. Wheat was used as a reference crop based on the average annual $C$ factor of 0.15 , determined for the Ethiopian highlands using runoff plot experiments (Hurni 1985). During this adjustment procedure, all proportions among the different crop classes, as well as the spatial variability of the $C$ factor, were maintained. The average annual $C$ factor values obtained are shown in table 2 in relation to average annual FVC values per land-use class.

Support Practice Factor P. Locally practised conservation in Faizabad often includes structural and vegetative measures. These are considered either in the $L$ factor (drainage 
Table 3

Overview of local conservation measures considered for scenario calculation on cropland.

\begin{tabular}{|c|c|c|c|c|c|}
\hline Name & Brief description & Application area & $\begin{array}{l}\text { Changes in RUSLE } \\
\text { calculated }\end{array}$ & $\begin{array}{l}\text { Soil loss } \\
\text { reduction* }\end{array}$ & $\begin{array}{l}\text { Cost } \\
\text { (US dollar ha }^{-1} \text { ) }\end{array}$ \\
\hline $\begin{array}{l}\text { Contouring } \\
\text { (C) }\end{array}$ & $\begin{array}{l}\text { Contouring: ploughing by } \\
\text { tractor along contour }\end{array}$ & $\begin{array}{l}\text { Annual and perennial } \\
\text { cropland or agroforestry } \\
\text { with a field slope }<15 \%\end{array}$ & $\begin{array}{l}P \text { factor (RUSLE) for } \\
\text { contouring by } \\
\text { Renard et al. } 1997\end{array}$ & $11 \%$ & No direct costs \\
\hline $\begin{array}{l}\text { Perennial } \\
\text { crops } \\
\text { (P) }\end{array}$ & $\begin{array}{l}\text { Perennial herbaceous fodder } \\
\text { crops: to improve vegetation } \\
\text { cover by cultivating esparzet } \\
\text { or alfalfa }\end{array}$ & $\begin{array}{l}\text { Fallow/abandoned } \\
\text { land or fields with } \\
\text { an inclination }>60 \%\end{array}$ & $\begin{array}{l}\text { Assign average } C \\
\text { factor for perennial } \\
\text { cropland }\end{array}$ & $16 \%$ & $\begin{array}{l}\mathrm{E}: 58 \\
\mathrm{R}: 12\end{array}$ \\
\hline $\begin{array}{l}\text { Drainage } \\
\text { ditches } \\
\text { (D) }\end{array}$ & $\begin{array}{l}\text { Drainage ditches and cut-off } \\
\text { drain: cut-off drain at top of } \\
\text { field to divert excessive } \\
\text { rainwater }\end{array}$ & $\begin{array}{l}\text { Annual and perennial } \\
\text { cropland, agroforestry, } \\
\text { and fallow/abandoned } \\
\text { land }\end{array}$ & $\begin{array}{l}\text { Set slope length to } 5 \mathrm{~m} \\
\text { (if slope }>25 \% \text { ) and } \\
\text { to } 10 \mathrm{~m} \text { (if slope } \\
\leq 25 \% \text { ) }\end{array}$ & $53 \%$ & $\begin{array}{l}\mathrm{E}: 11 \\
\mathrm{R}: 21\end{array}$ \\
\hline $\begin{array}{l}\text { Agroforestry } \\
\text { (A) }\end{array}$ & $\begin{array}{l}\text { Agroforestry: establishment of } \\
\text { fruit orchard trees on contour } \\
\text { with intercropping between } \\
\text { tree rows }\end{array}$ & $\begin{array}{l}\text { Annual and perennial } \\
\text { cropland and } \\
\text { fallow/abandoned land }\end{array}$ & $\begin{array}{l}\text { Set slope length to } \\
10 \mathrm{~m} \text { and assign } \\
\text { average } C \text { factor for } \\
\text { intercropped orchards }\end{array}$ & $63 \%$ & $\begin{array}{l}\mathrm{E}: 470 \\
\mathrm{R}: 210\end{array}$ \\
\hline $\begin{array}{l}\text { Terracing } \\
\text { (TA) }\end{array}$ & $\begin{array}{l}\text { Terraces and agroforestry: } \\
\text { terracing by machinery, and } \\
\text { then establishment of an } \\
\text { orchard with intercropping }\end{array}$ & $\begin{array}{l}\text { Annual and perennial } \\
\text { cropland and } \\
\text { fallow/abandoned land }\end{array}$ & $\begin{array}{l}P \text { factor for terracing } \\
\text { by Renard et al. } 1997, \\
\text { assign } C \text { factor for } \\
\text { intercropped orchards }\end{array}$ & $93 \%$ & $\begin{array}{l}E: 635 \\
R: 225\end{array}$ \\
\hline
\end{tabular}

ditches, agroforestry with tree rows along the contour) or in the $C$ factor (perennial crop cover). Terraces were established on an area 321 ha $(867 \mathrm{ac})$ in size during the Soviet era. Spatial distribution of terraced fields was derived from high-resolution satellite imagery. The soil loss reduction effect of terraces is accounted for in the standard $P$ factor calculation procedure for terracing proposed by Renard et al. (1997). Since no conservation measures other than contour tillage are practised on the large majority of fields in the study area, the support practice factor $P$ was set to 1 for nonterraced fields, equivalent to no conservation.

To assess the effect on soil erosion of the conservation measures studied (see following section on Local Conservation Measures), the factors described earlier were adjusted according to the typical layout of these measures.

Soil Loss Tolerance and Soil Loss Scenarios. Soil loss tolerance-the maximum rate of soil erosion that still allows crop productivity to be economically sustainable - is the foundation for soil conservation modeling (Renard et al. 1997). Renschler et al. (1998) and Schwertmann (1987) proposed an upper limit of $10 \mathrm{tha}^{-1} \mathrm{y}^{-1}\left(4 \mathrm{tn}^{-1} \mathrm{ac}^{-1} \mathrm{yr}^{-1}\right)$ for deep brown soils from loess formation. Soil loss frequently exceeds soil loss tolerance under current conditions. In this study, scenarios were calculated for three different soil loss tolerance values, adapting an approach by Shi et al. (2004). The soil loss tolerance values reflect the erosion rate classes "low" $(\leq 10 \mathrm{t}$ $\mathrm{ha}^{-1} \mathrm{y}^{-1}$, Scenario 10), "medium" ( $\leq 20 \mathrm{t} \mathrm{ha}^{-1}$ $\mathrm{y}^{-1}\left[8 \mathrm{tn}^{-1} \mathrm{ac}^{-1} \mathrm{yr}^{-1}\right]$, Scenario 20), and "high" $\left(\leq 30 \mathrm{t} \mathrm{ha}^{-1} \mathrm{y}^{-1}\left[12 \mathrm{tn}^{-1} \mathrm{ac}^{-1} \mathrm{yr}^{-1}\right]\right.$, Scenario 30). To begin with, local conservation measures were evaluated, and measures considered for scenario modeling were ranked according to their recurrent costs (table 3). Two lowcost measures were then applied throughout the study area. Finally, the predicted soil loss values were checked for every field and were compared to soil loss tolerance values, which had been set to 10, 20, and $30 \mathrm{t} \mathrm{ha}^{-1}$ $\mathrm{y}^{-1}$, depending on the different scenarios. For plots where soil loss still exceeded the tolerance threshold, additional conservation measures were proposed in the order of increasing recurrent costs. This procedure makes it possible to achieve optimal soil loss reduction while imposing the least costs on farmers.
Finally, the risk of RUSLE modeling by combining data with different quality levels and without formal calibration must be taken into consideration; multiplication of six factors, as done with the RUSLE, easily leads to large errors whenever a single input is misspecified (Nearing 1998; Sonneveld and Nearing 2003). Therefore, it should be stressed that absolute values presented in this study are mere estimations of soil loss and that all conclusions drawn from erosion and conservation modeling arise from relative comparisons.

\section{Results and Discussion}

Fractional Vegetation Cover and C Factor. Relating the FVC assessed in the field to OSAVI obtained from the QuickBird image, the following relationship was obtained: FVC $=-1.52$ OSAVI $^{2}+3.12$ OSAVI -4.59 , with a coefficient of determination $\left(r^{2}\right)$ of 0.68 . Testing against a validation dataset showed a coefficient of determination of 0.84 , suggesting high reliability for the FVC obtained from high-resolution satellite imagery.

The vegetation cover assessment for the whole study area revealed highly inhomogeneous vegetation cover within land-use 
classes, as documented in the boxplot in figure 2 showing median, quartiles (box), and $5 \%$ and $95 \%$ quantiles (whiskers). Flax fields, for example, had an FVC between 20\% and almost $100 \%$ on the recording date of the satellite image (lower quartile $=60 \%$, upper quartile $=79 \%$ ). Great FVC variability was observed for all crop classes.

Calculation of the $C$ factor for a specific plot is based on the plot's FVC cover at maximum vegetation height. The great variability observed for the FVC within each land-use class translates into a great disparity of $C$ factors between fields but within the same land-use class. This means that the $C$ factor can, at least to some extent, be influenced and managed by land users.

Furthermore, the annual $C$ factor as calculated for this study reflects seasonal changes of FVC over the year for each crop and is also related to semimonthly precipitation. This made it possible to determine seasonal susceptibility to erosion. While flax and vineyards showed similar FVC medians at maximum vegetation height, their annual $C$ factors differed significantly (flax [Linum usitatissimum $C=0.1749$; vineyards $C=$ 0.0767). This can be attributed to dissimilar FVCs during months of heavy rainfall in early spring. These results highlight the need to address $C$ factor variability for areas in Tajikistan when applying RUSLE modeling.

Predicted Soil Loss Under Current Conditions. Erosion rates resulting from the RUSLE calculations were classified into five erosion categories, ranging from very low to very high (figure 3 ).

Under current land-use practices, almost half of the cropland area shows low to very low erosion rates $\left(\leq 10 \mathrm{t} \mathrm{ha}^{-1} \mathrm{y}^{-1}\left[4 \mathrm{tn}^{-1} \mathrm{ac}^{-1}\right.\right.$ $\left.\left.\mathrm{y}^{-1}\right]\right)$. While moderate and high erosion rate categories (10 to 20 and 20 to $30 \mathrm{t} \mathrm{ha}^{-1} \mathrm{y}^{-1}$ [ 4 to 8 and 8 to $12 \mathrm{tn}^{-1} \mathrm{ac}^{-1} \mathrm{yr}^{-1}$ ]) are not as prevalent (13\% and $4 \%$ area cover), very high erosion categories $\left(>30 \mathrm{tha}^{-1} \mathrm{y}^{-1}\right)$ are predicted for more than a third of the area. Cropland showing low to moderate erosion rates is located mainly on the valley floor. Fields in the transition zone from the valley floor to the steep hillslopes are often exposed to high and very high erosion rates. Terraced land, for which very low erosion rates are predicted, and land on the valley floor is mainly cultivated by state farms, while sloping agricultural land is primarily leased out to to local farmers. This indicates that land users in Faizabad do not share the

\section{Figure 2}

Box plot showing the variability of vegetation cover within one crop class at the stage of maximum vegetation height using high-resolution remote sensing. Box marks indicate median, upper quartile, and lower quartile.

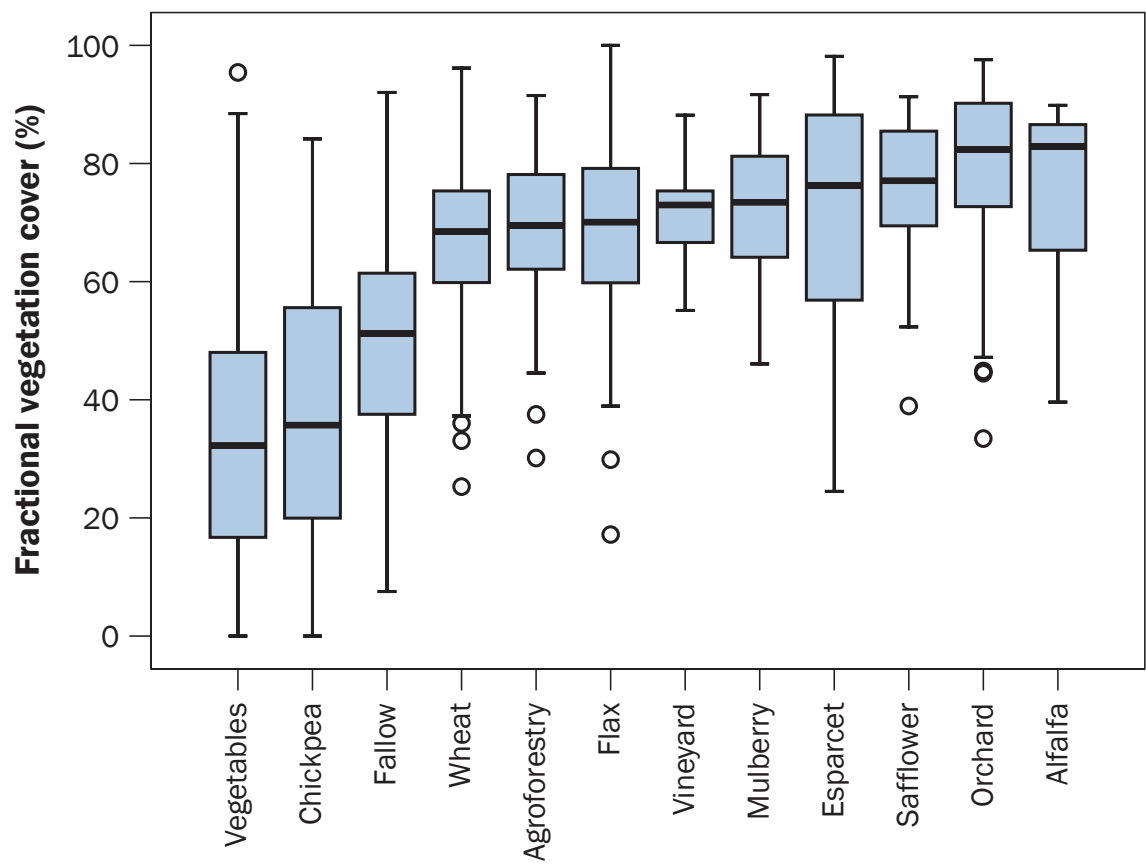

\section{Land use}

\section{Figure 3}

Current soil erosion on cropland (erosion categories).

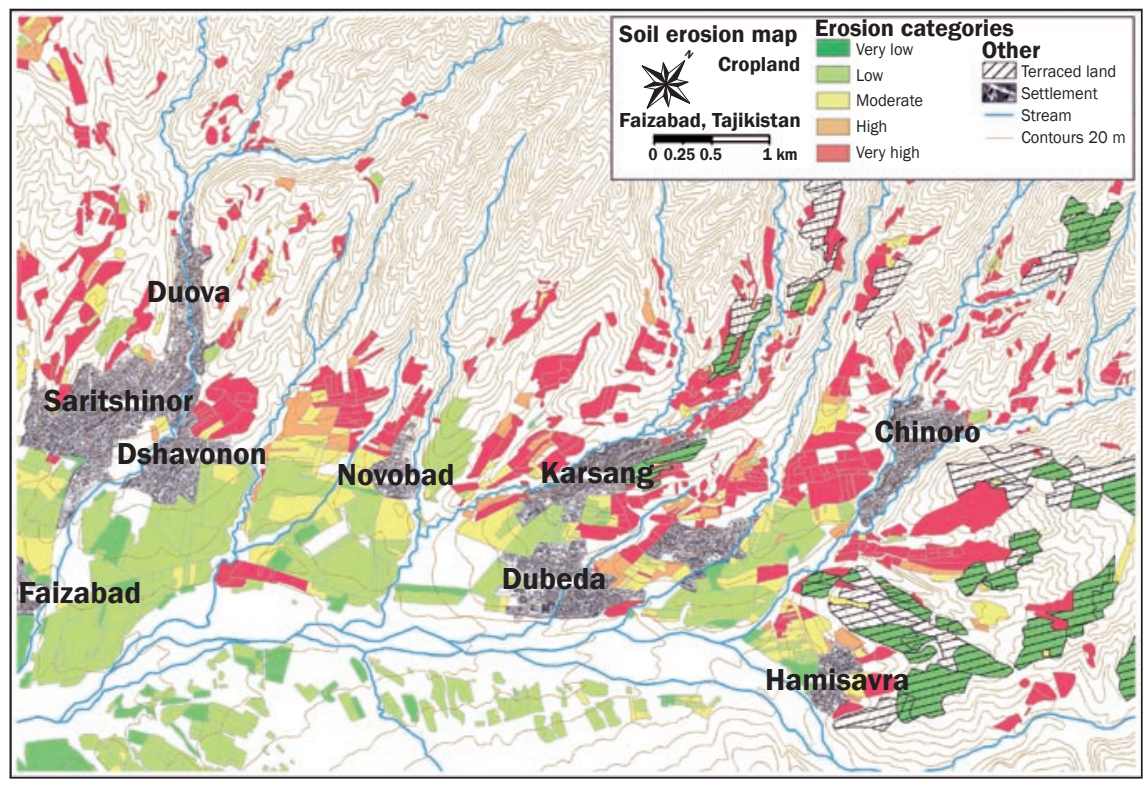

Source: Satellite image is from DigitalGlobe/Eurimage/swisstopo, NPOC. 
burden of soil erosion equally. Hence, there is a need for effective and affordable conservation measures that can be implemented by smallholders.

Local Conservation Measures. Currently, fields with implemented conservation measures account for $25.7 \%$ of the total cropland area (terraced fields, 20.2\%; fields under agroforestry, 3.6\%; and fields with perennial herbaceous fodder plants, $1.9 \%)$. These conservation measures were assessed in six case studies that are described in detail in the international database on the WOCAT Web site (technologies TAJ05 to TAJ10 and approaches TAJ05 and TAJ06) (WOCAT 2009). RUSLE computations revealed that low-cost agricultural measures such as contouring $(\mathrm{C})$, perennial herbaceous fodder plants $(\mathrm{P})$ and drainage ditches (D) entail soil loss reductions of $11 \%, 16 \%$, and $53 \%$, respectively, by comparison with current soil loss rates. The complex structural and vegetative measures of agroforestry alone (A) and terracing in combination with agroforestry (TA) have the potential to reduce soil erosion by as much as $63 \%$ and $93 \%$, respectively. While TA performs best of all measures at all slope angles, its effect is reduced almost by half at angles of less than 15\%. Hence, cost-intensive terracing measures do not pay on fields with moderate slope angles. Due to insufficient model validation, it should be stressed that the values presented may be inaccurate and that all conclusions drawn arise from relative comparisons.

A simple cost/benefit analysis focusing on the costs of soil conservation measures and their effects on soil loss conducted on the basis of WOCAT documentation made it possible to produce a rough assessment of the efficiency of different measures in reducing erosion (table 3), as well as to identify priority recommendations.

When recurrent costs are considered, agricultural measures such as $\mathrm{C}, \mathrm{D}$ and $\mathrm{P}$ are much more efficient in reducing soil erosion than A and TA. This fact may convince land managers to implement low-cost measures leading to rapid soil loss reduction on a majority of the agricultural fields in Faizabad. However, implementing low-cost measures alone may also entail disadvantages; if agronomic measures are not maintained annually, benefits from conservation will be reversed immediately. On the other hand, implementation of complex vegetative and structural measures will protect soil resources in the

\section{Figure 4}

Results of three scenarios. (a) Current and predicted distribution of soil loss classes on cropland area under different scenarios: soil loss tolerance values set at $30 \mathrm{t} \mathrm{ha}^{-1} \mathrm{y}^{-1}$ (Scenario 30), $20 \mathrm{tha}^{-1} \mathrm{y}^{-1}$ (Scenario 20), and $10 \mathrm{t} \mathrm{ha}^{-1} \mathrm{y}^{-1}$ (Scenario 10). (b) Area distribution of the current condition and conservation measures on cropland under Scenarios 30, 20, and 10.

(a)

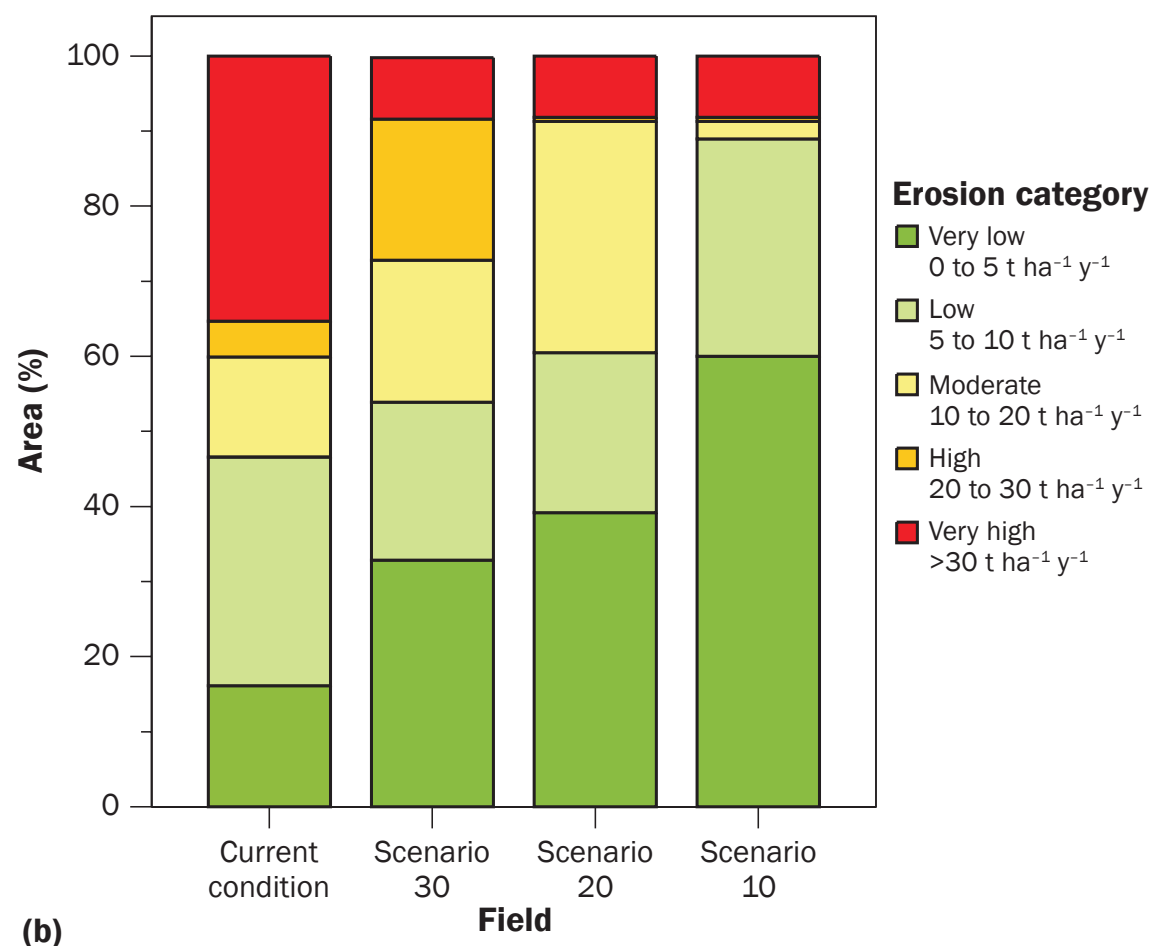

(b)

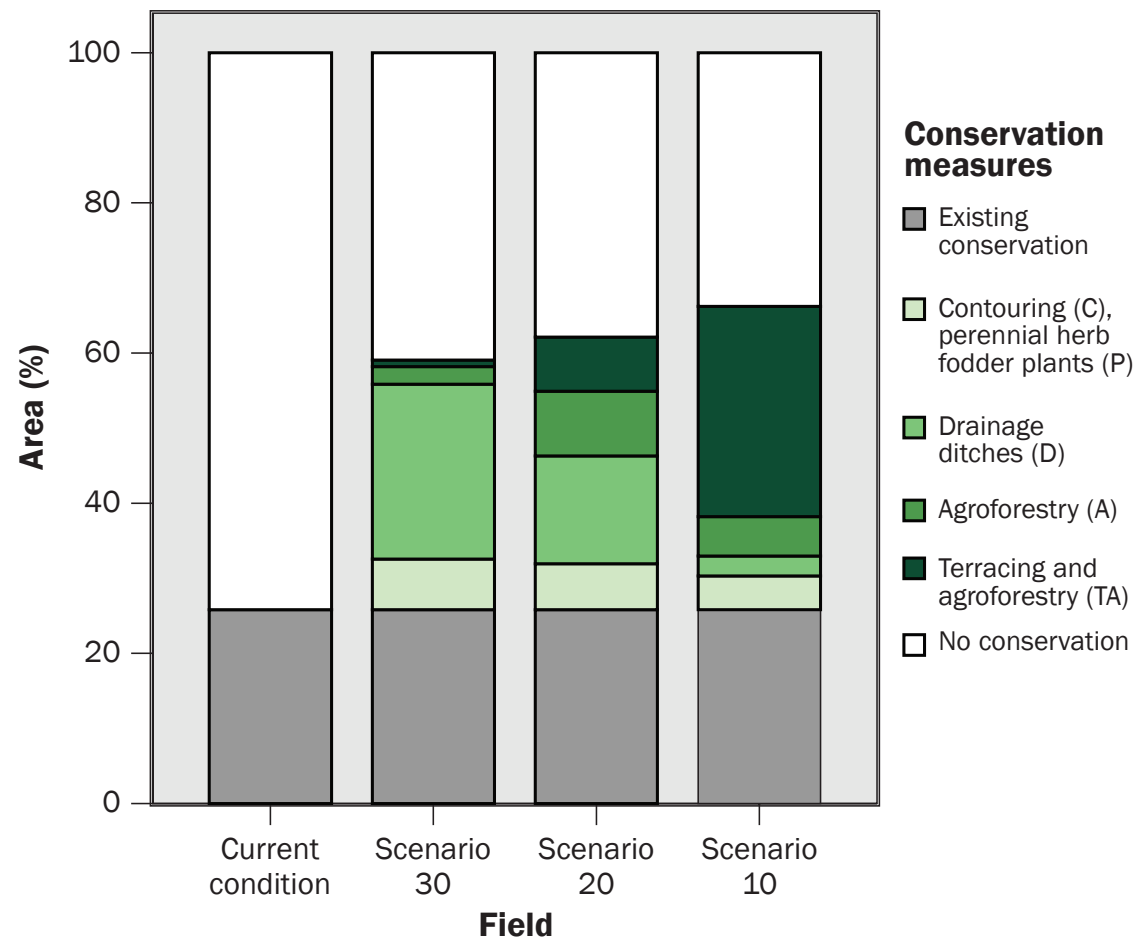


long term. For this reason, A and TA need to be considered, especially for areas with a high risk of soil erosion.

Results of Scenarios for Soil Loss Reduction. Three scenarios were computed, corresponding to soil loss tolerance values of 10, 20, and $30 \mathrm{t} \mathrm{ha}^{-1} \mathrm{y}^{-1}\left(4,8\right.$, and $12 \mathrm{tn}^{-1} \mathrm{ac}^{-1}$ $\left.\mathrm{yr}^{-1}\right)$. The results are compared to the current situation in figure 4 . Figure 4 a shows results expressed as a percentage of area for the soil loss classes very low to very high. The proposed conservation measures achieve the targets for the respective Scenarios $(<30$, $<20$, and $<10 \mathrm{t} \mathrm{ha}^{-1} \mathrm{y}^{-1}$ ) with one exception. Erosion remains very high $\left(>30 \mathrm{t} \mathrm{ha}^{-1} \mathrm{y}^{-1}\right)$ on about $8.1 \%$ of the land. On these plots, it is not possible to reduce erosion further by means of the assessed conservation measures, since terracing is not practicable in existing orchards and agroforestry systems. Additional conservation measures need to be identified for these areas. At the same time, in other areas, the proposed measures lead to a great increase in the very low erosion class $\left(<5 \mathrm{t} \mathrm{ha}^{-1} \mathrm{y}^{-1}\left[2 \mathrm{tn}^{-1} \mathrm{ac}^{-1} \mathrm{yr}^{-1}\right]\right)$. The percentage of the area here increases from $16 \%$ under current conditions to more than $30 \%$ in Scenarios 30 and 20 and as high as $60 \%$ in Scenario 10. Soil erosion rates on cropland in the study area are more than halved $(-53 \%)$ in Scenario 30, while Scenarios 20 and 10 both reduce erosion by an additional $8 \%$ and $10 \%$, respectively. Under Scenario 10, soil loss on cropland may thus be reduced by as much as $71 \%$ by comparison with current values.

Figure $4 \mathrm{~b}$ shows the corresponding area coverage for conservation measures required to reduce soil loss beyond the tolerance level of the respective scenario. All three scenarios have a similar overall area on which implementation of conservation measures is necessary $(33.1 \%$ to $40.2 \%)$. However, there are distinct differences in the type of conservation measures to be applied. To achieve the target of Scenario 30, which is to prevent very high soil erosion rates $\left(>30 \mathrm{tha}^{-1} \mathrm{y}^{-1}[12\right.$ $\left.\left.\mathrm{tn}^{-1} \mathrm{ac}^{-1} \mathrm{yr}^{-1}\right]\right)$, low-cost agricultural measures $\mathrm{C}$ and $\mathrm{P}$ together with $\mathrm{D}$ are sufficient on $30 \%$ of the cropland area. Measures A and TA are necessary on only $3.2 \%$ of the cropland area. In Scenario 20, the area percentage of C and $\mathrm{P}$ remains largely constant, while the area percentage where drainage proved sufficient to achieve the target in Scenario 30 now requires the costlier measures A and TA (both at an area coverage of almost 10\%). Finally, in Scenario 10, there is a rapid increase in the need for terracing with agroforestry. The area requiring implementation of these systems increases from $7 \%$ of the cultivated area in Scenario 20 to $28 \%$ in Scenario 10, i.e., when targeting soil loss rates below $10 \mathrm{t} \mathrm{ha}^{-1}$ $\mathrm{y}^{-1}\left(4 \mathrm{tn}^{-1} \mathrm{ac}^{-1} \mathrm{yr}^{-1}\right)$.

These promising soil loss reduction figures raise questions about the feasibility of the various scenarios. The WOCAT interviews revealed that the implementation costs of a measure influence farmers' decisions about investments in soil conservation. Failure to meet recurrent maintenance costs for a measure may prevent the expected extra returns - such as improved fruit yields in agroforestry systems-from being generated and cause the conservation measure to lose its expected effectiveness. In conclusion, a scenario can only be achieved if the land users are in a position to bear the costs. The fact that Scenario 10 can be achieved on almost half of the cropland area only by implementing the complex and costly measures A and TA implies that present land-use practices on these fields are not appropriate under their specific conditions. For this reason, the present use of these fields should be reconsidered before implementing costly conservation measures, especially on severely eroded land. On the other hand, if soil erosion rates are to be brought close to sustainable levels under current land use-which would imply aiming for Scenario 10-substantial public investment in and extended support for conservation will be needed. An expected increase in yield on successfully conserved fields is likely to provide a return on investment.

\section{Summary and Conclusions}

The study shows that integrating field methods applied at several different sampling levels into RUSLE modeling is a promising way of combining methods in accordance with their specific strengths. It allows for rapid and easy application. Integration of only six case studies on local conservation measures using detailed information collected with WOCAT questionnaires led to a better understanding of the functioning of these measures and provided the basis for a simple cost analysis. This in turn made it possible to ensure that the majority of recommended measures are affordable for local land users and that the need for public support is recognised at an early stage in conservation planning wherever this is not the case.

The RUSLE approach presented here is based on modest data requirements - a common limitation in developing nations. Its practical utility is based on providing a means for evaluating the effects of conservation practices on current soil erosion by relative comparison, rather than on its prediction of absolute soil erosion values.

When applying the RUSLE to larger areas, and especially areas with an inhomogeneous vegetation cover, the integration of plotbased cover, derived most efficiently from high-resolution satellite imagery, is vital to enable plot-wise conservation planning. We suggest that crop-specific, seasonally adjusted $C$ factors be calculated on the basis of FVC at field plot resolution.

RUSLE modeling proved suitable for straightforward scenario modeling. Thorough field assessments showed that $25.7 \%$ of current total cropland is covered by conservation measures (terracing, agroforestry, and perennial herbaceous fodder). Assessment of the effectiveness of these local measures, combined with the RUSLE calculations, revealed that current average soil loss could be reduced through low-cost measures such as contouring (by 11\%), fodder plants (by 16\%), and drainage ditches (by 53\%). More expensive measures, such as terracing and agroforestry, can reduce erosion by as much as 63\% (for agroforestry) and 93\% (for agroforestry combined with terracing).

Indeed, scenario runs for different levels of tolerable erosion rates showed that more cost-intensive and technologically advanced measures would lead to greater soil loss reduction. However, given the economic conditions in Tajikistan, it seems advisable to support the spread of low-cost measures that are both more cost-effective and locally known and accepted.

\section{Acknowledgements}

We are grateful to the Swiss National Center of Competence in Research North-South for providing financial support for this study and to the Soil Science Research Institute of the Tajik Academy of Agricultural Science for assistance in scientific, administrative, and organizational matters during data collection. In this respect, we particularly acknowledge the contribution of Gulniso Nekushoeva from Dushanbe, a $\mathrm{PhD}$ candidate in the Swiss National Center of Competence in Research North-South program. We are also grateful for collaboration with the WOCAT team. Last but not least, we greatly appreciated the sincere collaboration of land users 
who provided us with valuable and usually otherwise inaccessible primary information.

\section{References}

Academy of Science Tajikistan. 1984. Agropromyshlennye usloviia i resursy (Agricultural conditions and resources [in Russian]). Dushanbe: Academy of Science Tajikistan.

Benkobi L., M.J. Trlica, and J.L. Smith. 1994. Evaluation of a redefined surface cover subfactor for use in RUSLE. Journal of Range Management 47(1):74-78.

Cohen, M.J., K.D. Shepherd, and M.G. Walsh. 2005. Empirical reformulation of the Universal Soil Loss Equation for erosion risk assessment in a tropical watershed. Geoderma 124(3-4):235-252.

DigitalGlobe/Eurimages/swisstopo. 2005. Quickbird multispectral satellite image, resolution $2.4 \mathrm{~m}(7.9 \mathrm{ft})$, recorded on June 22, 2005.

Ding, Z.L., V. Ranov, S.L.Yang, A. Finaev, J.M. Han, and G.A. Wang. 2002. The loess record in southern Tajikistan and correlation with Chinese loess. Earth and Planetary Science Letters 200(3-4):387-400.

Fernandez, C., J.Q. Wu, D.K. McCool, and C.O. Stöckle. 2003. Estimating water erosion and sediment yield with GIS, RUSLE, and SEDD. Journal of Soil and Water Conservation 58(3):128-136.

Gaffer, R.L., D.C. Flanagan, M.L. Denight, and B.A. Engel. 2008. Geographical information system erosion assessment at a military training site. Journal of Soil and Water Conservation 63(1):1-10, doi:10.2489/jswc.63.1.1.

Hickey, R. 2000. Slope angle and slope length solutions for GIS. Cartography 29(1):1-8.

Hudson, N. 1995. Soil Conservation. Ames: Iowa State University Press.

Hurni, H. 1985. Erosion-productivity-conservation systems in Ethiopia. In Proceedings of the IV International Conference on Soil Conservation, 654-674. Maracay, Venezuela: IV International Conference on Soil Conservation.

Jakutilov, M.R., A.M. Burikin, and A.A. Sadriddinov. 1963. Pochvy Tadzhikistana - eroziya pochv i borba s'ney (Soils of Tajikistan - soil erosion and the fight against it [in Russian]). Dushanbe: Tadjik Gosisdat.

Kuteminskij, V.J., and R.S. Leonteva. 1966. Pochvy Tadzhikistana (Soils of Tajikistan [in Russian]). Dushanbe: IRFON.

Lal, R. 2001. Soil degradation by erosion. Land Degradation \& Development 12(6):519-539.

Lin, C.Y., W.T. Lin, and W.C. Chou. 2002. Soil erosion prediction and sediment yield estimation: The Taiwan experience. Soil \& Tillage Research 68(2):143-152.

Liniger, H.P., and W. Critchley. 2007. Where the Land is Greener. Case Studies and Analysis of Soil and Water Conservation Initiatives Worldwide. Wageningen: Technical Center for Agricultural and Rural Cooperation.
Mannaerts, C.M., and D. Gabriels. 2000. Rainfall erosivity in Cape Verde. Soil \& Tillage Research 55:207-212.

Merritt, W.S., R.A. Lecher, and A.J. Jakeman. 2003. A review of erosion and sediment transport models. Environmental Modelling and Software 18(8-9):761-799.

Nearing, M.A. 1998. Why soil erosion models over-predict small soil losses and under-predict large soil losses. Catena 32(1):15-22.

Pimentel, D., J. Alien, and A. Beers. 1993. Soil erosion and agricultural productivity. In World Soil Erosion and Conservation, ed. David Pimentel, 277-309. Cambridge: Cambridge University Press.

Renard, K.G., G.R. Foster, G.A. Weesies, D.K. McCool, and D.C. Yoder. 1997. Predicting Soil Erosion by Water: A Guide to Conservation Planning with the Revised Universal Soil Loss Equation (RUSLE). Agriculture Handbook 703. Washington, DC: USDA.

Renschler, C.S., C. Mannaerts, and B. Diekkrüger. 1998 Evaluating spatial and temporal variability in soil erosion risk-rainfall erosivity and soil loss ratios in Andalusia, Spain. Catena 34(3-4):33-48.

Rondeaux, G., M. Steven, and F. Baret. 1996. Optimisation of soil-adjusted vegetation indices. Remote Sensing of Environment 55(2):95-107.

Schwertmann, U. 1987. Bodenerosion durch Wasser: Vorhersage des Abtrags und Bewertung von Gegenmaßnahmen (in German). Stuttgart: Eugen Ulmer.

Schwilch, G., F. Bachmann, and HP. Liniger. 2009 Appraising and selecting conservation measures to mitigate desertification and land degradation based on stakeholder participation and global best practices. Land Degradation and Development 20:308-326.

Shi, Z.H., C.F. Cai, S.W. Ding, T.W. Wang, and T.L. Cho. 2004. Soil conservation planning at the small watershed level using RUSLE with GIS: A case study in the Three Gorge Area of China. Catena 55(1):33-48.

Shiono, T., K.I. Kamimura, S. Okushima, and M. Fukumoto 2002. Soil loss estimation on a local scale for soil conservation planning. Japan Agricultural Research Quarterly 36(3):157-161.

Sonneveld, B.G.J.S., and M.A. Nearing. 2003. A nonparametric/parametric analysis of the Universal Soil Loss Equation. Catena 52(1):9-21.

Van Remortel, R., M. Hamilton, and R. Hickey. 2001. Estimating the LS factor for RUSLE through iterative slope length processing of digital elevation data. Cartography 30(1):27-35.

Van Remortel, R.D., and L. Martin. 2003. Bob's slope page. Arc macro language (AML) script calculating LS factor using DEM data according to RUSLE-based criteria. rusle_ls_4_pc.aml (draft Dec. 2003). http://www. onlinegeographer.com/slope/slope.html.
Vrieling, A. 2006. Satellite remote sensing for water erosion assessment: A review. Catena 65(1):2-18.

Wang, G., S. Wente, G.Z. Gertner, and A. Anderson. 2002. Improvement in mapping vegetation cover factor for the Universal Soil Loss Equation by geostatistical methods with Landsat thematic mapper images. International Journal of Remote Sensing 23(18):3649-3667.

Wischmeier, W.H., and D.D. Smith. 1978. Predicting Rainfall Erosion Losses - A Guide to Conservation Planning. Agriculture Handbook No.282. Washington, DC: USDA.

WOCAT (World Overview of Conservation Approaches and Technologies). 2005a. Questionnaire on SWC Approaches. A Framework for the Evaluation of Soil and Water Conservation. Bern: University of Berne Center for Development and Environment.

WOCAT. 2005b. Questionnaire on SWC Technologies. A Framework for the Evaluation of Soil and Water Conservation. Bern: University of Berne Center for Development and Environment.

WOCAT. 2009. Database on SLM Technologies and Approaches. http://www.wocat.net/en/knowledgebase/technologiesapproaches.html.

Wolfgramm, B. 2007. Land Use, Soil Degradation and Soil Conservation in the Loess Hills of Central Tajikistan. $\mathrm{PhD}$ dissertation. University of Bern.

Yang, D., S.K. Kanae, T. Oki, T. Koike, and K. Musiake. 2003. Global potential of soil erosion with reference to land use and climate changes. Hydrological Processes 17(14):2913-2928.

Zhang, G.H., M.A. Nearing, and B.Y. Liu. 2005 Potential effects of climate change on rainfall erosivity in the Yellow River Basin of China. Transactions of the American Society of Agricultural Engineers 48(2):511-517.

Ziadat, F.M. 2007. Effect of contour intervals and grid cell size on the accuracy of DEMs and slope derivatives. Transactions in GIS 11:67-81. 